\title{
CENTRAL GOVERNMENT COMMUNICATION WITH REGIONS IN HANDLING COVID-19 IN DKI JAKARTA THROUGH SOCIAL MEDIA
}

\author{
Vindhi Putri Pratiwi ${ }^{1}$, Sanny Nofrima ${ }^{2 *}$, Titin Purwaningsih ${ }^{3 *}$ \\ ${ }^{1,2,3}$ Universitas Muhammadiyah Yogyakarta, Indonesia \\ *sannynofrima21@gmail.com
}

\begin{abstract}
This article aims to find out the communication relationship between the central government and local government in handling Covid-19. In analyzing the data using descriptive qualitative methods and processed using NVIVO 12 Plus is a processed data application to analyze online and social media data so that researchers can use the application to manage the data until there is no set time limit. Handling the spread of coronavirus is the responsibility of the central government. However, since the decentralization in Indonesia, it is also the authority of the local government itself to determine the policies that must be carried out related to the handling of the coronavirus or covid-19 outbreak. DKI Jakarta is one of the areas exposed to corona virus with the most confirmed cases. Policies carried out by local governments are also in a race against the policies of the central government. So that there is a good communication intergration between the central government and local government.
\end{abstract}

Keywords: Covid-19, Government Communications, Policy

\begin{abstract}
Abstrak
Artikel ini bertujuan untuk mengetahui hubungan komunikasi pemerintah pusat dengan pemerintah daerah dalam penanganan Covid-19. Dalam menganalisis data menggunakan metode kualitatif deskriptif dan diolah menggunakan NVIVO 12 Plus merupakan aplikasi olahan data untuk menganalis data media online dan social sehingga peneliti bisa mengunakkan aplikasi untuk mengelolah data hingga tidak ada batasan waktu yang tetapkan. Penanganan penyebaran virus corona merupakan tanggung jawab pemerintah pusat. Akan tetapi semenjak adanya desentralisasi di Indonesia, hal ini juga menjadi kewenangan pemerintah daerah sendiri untuk menentukan kebijakan yang harus dilakukan terkait dengan penanganan wabah virus corona atau covid-19. DKI Jakarta merupakan salah satu daerah yang terpapar corona virus dengan kasus yang terkonfirmasi paling banyak. Kebijakan yang dilakukan oleh pemerintah daerah juga berpacu kepada kebijakan yang dilakukan oleh pemerintah pusat. Sehingga perlu adanya intergrasi komunikasi yang baik antara pemerintah pusat dengan pemerintah daerah.
\end{abstract}

Kata Kunci: Covid-19, Komunikasi Pemerintahan, Kebijakan

\section{INTRODUCTION}

Coronavirus or covid-19 outbreak becomes a non-natural disaster of a global nature. The type of pneumonia triggered by the novel coronavirus disease 2019 (COVID-19) is a highly contagious disease and WHO calls this outbreak a global public health (Chinazzi et al., 2020). Starting in December 2019, Chinese health authorities have been monitoring a group of pneumonia cases in wuhan city area, in Hubei province,
The pathogen that causes viral pneumonia among affected individuals is the new SARS-CoV-2 coronavirus (Chinazzi et al., 2020)Corona Virus Disease 2019 (Covid19), a pandemic outbreak indicated from Wuhan China has now spread in more than 128 countries with a positive number of 540,000 people (Spectatorindex, n.d.).

Coronavirus outbreak is still no vaccine that can cure, but there are several ways to minimize the spread of coronavirus. 
As stated by (Hopman, Allegranzi, \& Mehtar, 2020) that the spread of Covid-19 may be suppressed by knowing more quickly about identified people, where the government focuses on checking on its people. So by knowing more quickly, it is able to minimize the spread of covid-19 in an area. In addition, in the United Kingdom (UK) which is one of the countries affected by the spread of the coronavirus or covid-19 outbreak shows that government policies that can reduce the number of deaths between $78 \%-99 \%$ can be done by applying genral social distancing which includes selfisolation, household quarantine, school and university closures (Ferguson et al., 2020). Various countries have different variants of policy response including Lockdown (China, Italy, India), Herd Immunity (UK). In terms of re-allocation of the budget the Malaysian government cut the salaries of 2 months ministry officials, South Korea cut $30 \%$ of salaries or New Zealand implemented Wage Subsidy Payment.

One of the countries affected by the coronavirus outbreak is Indonesia. Where until March 27, 2020, 1046 people have been indicated positive for coronavirus, as many as 87 people died and 46 people managed to recover (Bayu, 2020). This can be interpreted that the death rate related to the coronavirus outbreak in Indonesia can reach $8.3 \%$. However, with the increasing covid19 pandemic in Indonesia, the central government and local governments must continue to synergize to try to suppress the spread of coronavirus or covid-19. In Indonesia in vulnerable January-February, it still opens the taps of tourist visits, investment and influencer promotions worth 72 billion, where one of the implications is that the surge in casualties increased dramatically in March. There were 1,046 confirmed positive cases, 913 in treatment, 46 cured, and 87 died (kawalcovid19.id, $27 / 03 / 2020$ ). Colored by the dynamics of public pros and limited health and economic infrastructure, now the policies of Social
Distancing, Rapid Test and Work From Home (WFH) are chosen by the Indonesian government. Through the Presidential Decree No. 7/2020, a Task Force for the Acceleration of Handling COVID-19 was established, there was a re-allocation of the ministry's budget and a special Recovery Bond for the private sector.

Handling the spread of coronavirus is the responsibility of the central government. However, since the decentralization in Indonesia, it is also the authority of the local government itself to determine the policies that must be carried out related to the handling of the coronavirus or covid-19 outbreak. However, there needs to be integrated communication between the central and local governments on policies made by local governments in handling Covid-19. Where at this time the coronavirus outbreak has had an impact on the region as well, so that local governments have the authority to provide policies in handling the spread of Covid-19 by still racing on policies carried out by the government. One of the areas most affected by the Covid-19 pandemic with the highest number of cases is the DKI Jakarta area. Where to date cases in DKI Jakarta have reached 7,383 who were declared positive. Since the beginning of covid-19 cases in DKI Jakarta on March 2, 2020, the local government has tried to reduce the rate of covid-19 transmission.

Looking at the current condition of Indonesia is still in the middle of the outbreak journey and still far from the end point, it is not wise for us to assess the effectiveness of national leadership in the face of the Covid-19 pandemic because the data is still dynamic and continues to grow (Solahudin, Eif, Amin, Sumpena, \& Hilman, 2020). Even worse is the low level of public awareness on psbb rules. According to a search by CSIS researcher Noory Oktariza at the Jakarta Post, movement in and out of Jakarta since April 3, 2020 remains high (Thorik, 2020). The implementation of policies in the reduction of COVID-19 
disaster in Indonesia in the form of territorial quarantine policies and social restrictions with strict restrictions on group movements and except for economic purposes, not to leave home and work from home has an important effect and impacts on the informal sector and daily workers (Ansori, 2020).

Various information related to the handling of Covid-19 both by the central government and local governments are always in communication to the community. Communication between citizens or the community with the government, both can be as communicators where the community will become communicators if the community as the initiator of ideas and the government as a communicator if the government as the information presenter (Alfiani, Kurniawati, \& Siwi, 2018). Because government communication as the delivery of information a program, policies, and ideas from the government to become a vision and mission to the community (Anggreani, Purnomo, \& Kasiwi, 2020).

Government communication can consist of two forms of communication, namely internal communication and external communication (Abidin, 2016). During the COVID-19 pandemic, government communication in the form of external communication in which the process of conveying information is carried out by the government to the public as well as information received from the public by the government. So that communication creates interaction between the government and the community. The government needs good communication in the delivery of the policy process from conception to policy implementation (Gregory, 2006). So that government communication is not only a means or tool for the government to convey and or receive information about a public policy, for example, but also as a means of integrating activities in an organized way in realizing cooperation (Silalahi, 2004). Therefore, this article will look at the communication relationship between the central government and local governments in handling Covid-19 through social media.

\section{METHODOLOGY}

The era of massive digital change is changing the nature of communication and through the way we research through Big data it is at the crossroads of technology to change reality. Online news media with sites that offer editorial content options, both provided by the parent media that is connected to deliberate production for the version. Events or events that occur in the field can be uploaded directly in minutes or seconds. Thus accelerating the distribution of information to the media, through global reach via the internet network, and in time hand in hand through online news. In addition to the way online news operates in terms of rapid distribution of information, information or old data can be reopened at any time with material delivered in a variety of ways, including text, images, audio, and video. However, there are gaps in online media information that isn't always reliable or total, so readers must be more cautious to prevent inaccurate information.

The library studies/research libraries are included in this study. Literature review, bibliography review, theoretical review, Foundation theory, and theoretical review are all terms used to describe the study of literature. Despite the fact that it is a survey, literature studies do not necessitate going out into the field to meet with respondents. According to (Zed, 2014), library tracing is used in library research not just for the initial phase of setting up a research design, but also to collect research data. In addition to statistics, some aspects of a study that must be included in order for it to be scientifically valid include problem design, foundation theory, data interpretation, and conclusionmaking. The source and method of data collection for research with the study of literature is retrieving data from the library, reading, documenting, and processing research materials, which is similar to other 
research. To produce results, research literature studies necessitate a detailed and in-depth review. Since the data collection is performed with a technique in the form of research methodology, research with the study of literature is also a study and can be classified as a scientific work. The variables in literature review studies are not unprocessed. The author conducts a thorough analysis of the data collected. To address the formulation of research problems, the data is poured into subchapters.

In this study, researchers used qualitative approach method. Qualitative method is research conducted on natural objects that develop by using research instruments, namely people or human instruments. This method uses in-depth data, data containing (Sugiyono, 2018). In the presentation of the findings used descriptive types because researchers want to see the problems that will be searched through the description, identification and analysis of data through google trends to find out the information that is often searched by the public. As Bachri (2010) said, qualitative method is research that aims to describe and analyze phenomena, events, social activities, attitudes, perceptions, thoughts of individuals or in groups (Bachri, 2010).

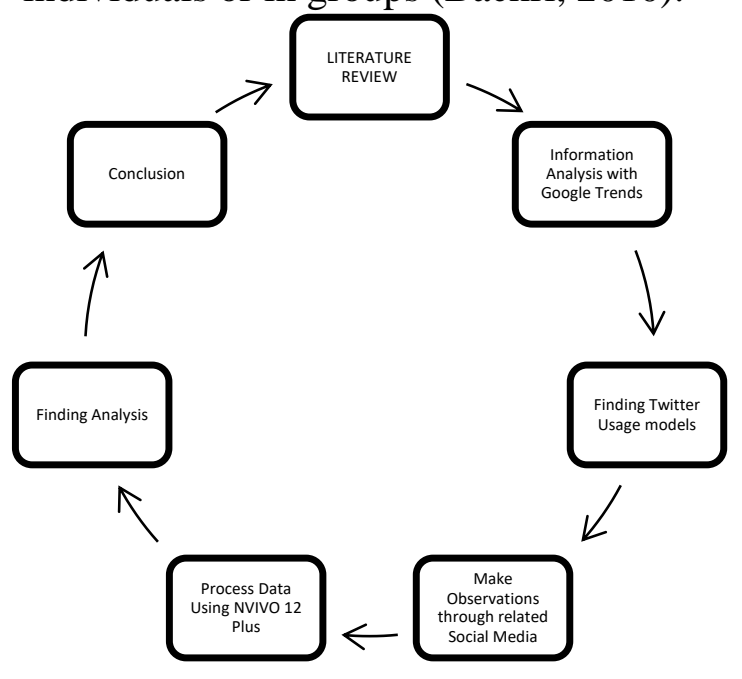

Figure 1. Research Flow Source : Processed by Researchers, 2021
Data management in this study using data processing tool namely NVivo12 plus (figure 1).

This research began by conducting literature review to find problems related to research and data that support the research, then researchers conducted data retrieval using Google Trend and Ncapture after that processed directly with the help of nvivo 12 plus data processing software which is a software used to automatically process existing data, then data analysis through data that has been processed using Nvivo 12 Plus. The results that existed then became the analysis material continued to be the conclusion of the research. The data in this study authors conducted research using relevant journals and literature from various sources of literature studies, then social media data obtained by processing the data of the central government's twitter social media accounts through the account of the Ministry of Health of the Republic of Indonesia by using the help of Nvivo 12 Plus. New media allows for more accessible and versatile use, but it can also lead to confusion. The advent of digital media, which heralds a new age in interactive technology and network communication, especially through cyberspace, will transform society.

\section{RESULT AND DISCUSSION}

In addition to the way online news operates in terms of rapid distribution of information, information or old data can be reopened at any time with material delivered in a variety of ways, including text, images, audio, and video. However, there are gaps in online media information that isn't always reliable or total, so readers must be more cautious to prevent inaccurate information. Political ethics is one of the initiatives that allows social institutions to redistribute basic rights and responsibilities, as well as decide the allocation of income oriented to justice, in the development of government policies for particular purposes in society and 
government. Furthermore, public policy and implementation is a program that includes all stakeholders, including the government, public, and private initiatives aimed at meeting the policy's objectives. Policy is described as an action proposed by a person, party, or government in a specific context that offers challenges and opportunities for policies to resolve or achieve a specific goal.

Communication as an important thing in social relations, where communication will create community relations interaction with each other (Kosasih, 2016). Communication cannot be separated from the social structure of people's lives, because communication becomes important as a process of information exchange. When looking at the government, government communication becomes an important thing that egera done as in the current pandemic. Where the government as the most important sector in handling covid-19 cases.

During the COVID-19 pandemic, government communication needs to be built to create interactive and communicative interactions with the community. Government communication during the pandemic can also create information disclosure from the government to the public. One of the media that can be used by the government to build interaction with the community quickly is through social media. Because social media platforms can be a place to communicate government achievements or create space for discussion with the public (Belkahla Driss, Mellouli, \& Trabelsi, 2019).

The Covid-19 pandemic in various countries, one of which is Indonesia, is a major problem for aspects of life, both economic and social. Therefore, there needs to be a role of the central government and local government in reducing the rate of Covid-19 transmission. Not only developing countries are experiencing problems from the Covid-19 pandemic, but developed countries are also having an impact from this pandemic. Therefore, the conversation about Covid-19 has become sharply increasing, where people are always looking for Covid19 in the world's largest search engine, namely through Google. The existence of google search engine, the public can easily access related information about Covid-19 both at the regional and international levels. In addition, Google also provides convenience for the public to know things that are being discussed in public, the feature is called google trends.

According to (Riyanto, 2014), Google Trends can be used to research what the author is looking for and Google Trends is able to display alternative keywords related to research, with the keyword indicating a high rating that has been analyzed using Google Trends. How to retrieve data through google trends is the main step to open google trends with google account, on the initial page of map view then search for keywords or keyword in google trends to be able to find keywords related to research topics other than and compare with keyword that has been determined by the author.

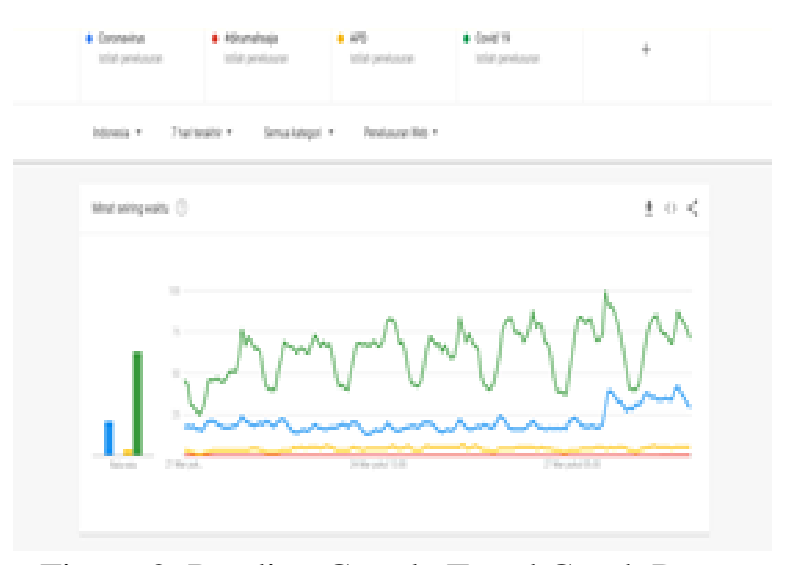

Figure 2. Reading Google Trend Graph Data Source : Processed by researchers using Google Trends, 2020.

Based on the figure 2, searches related to coronavirus, \#dirumahaja, and Covid-19 have increased, especially in the Covid-19 trend. This is because, Covid-19 has only just begun to spread in Indonesia so 
that the public wants to know related to the pandemic caused by the corona virus. Thus, social media trends in providing information related to Covid-19 also experienced a sharp increase. The existence of trends related to Covid-19 both on the internet and social media can also have an impact on the social aspects of society. Where the information obtained by the community can cause panic for the community itself. It cannot be expected that the main clear effect of the pandemic outbreak is the intensive psychological effect as a form of moral panic that spreads thoroughly with intense feelings and stigma over the clarity of the end of the pandemic (Chen et al., 2020).

Therefore, it becomes important for the government in reducing excessive anxiety in the community (Nicomedes \& Avila, 2020). Thus, the purpose of communication must be required to be able to create conditions that do not promote incorrect information and can provide public panic that should not be necessary to get an unwanted response (Wing et al., 2020).The role of government communication in handling COVID-19 needs to be built by creating communication strategies so as not to cause disinformation or disinformation of public perception to the bad government. So that communication by government actors needs to be done to be able to provide an answer on the spread of information related to Covid-19 in the mass media and social media. It is necessary to integrate between the central government and local governments in communicating related to policies carried out by the government in reducing the rate of transmission of the Covid-19 virus. At the beginning of the Covid 19 case, the Indonesian government immediately gave a policy to conduct social restrictions or social distancing. This policy tries to ask the public to encourage social activities and provide distance between one person and another. According to (WilderSmith \& Freedman, 2020), that social distancing is designed to reduce interaction between communities in the wider community, where individuals can transmit but have not been identified so that the individual does not perform isolation. Social distancing is considered effective in breaking the chain of distribution among communities that already have local transmission cases, but can be less effective in communities that do not have adequate case distribution data. Therefore, the policy carried out by the Indonesian government to date is to implement social distancing to reduce the rate of Covid-19 transmission where it will be effectively carried out at this time does not have adequate case distribution data. Therefore, the policy carried out by the Indonesian government to date is to implement social distancing to reduce the rate of Covid-19 transmission which will be effective at this time. In addition to social distancing policy the government also advises the public to conduct self quarantine or self-quarantine in order to reduce activities carried out outside the home. Self quarantine is ultimately causing the policy of the local government itself, namely with the quarantine area. It is considered effective to be able to prevent outside communities from entering the area.

In conducting communication, local governments need to synchronize policy information in handling Covid-19 in accordance with the policies provided by the Central Government. So, in this pandemic condition communication through mass media and social media becomes effective to remain synergistic between the central government and local governments. Some agencies related to handling covid-19, both from the government and NGOs, also often spread information through social media Twitter, for example through official twitter accounts of institutions such as @ kemenkesRI accounts or @BNPB_Indonesia accounts to several personal accounts of regional heads, such as the governor of DKI Jakarta, Anies Baswedan, governor of West Java, Ridwan 
Kamil and the Governor of Central Java, Ganjar Pranowo. Because of this that one of the social media that is very suitable and effective in the process of disseminating information is Twitter, especially general information about suat activities or events (Gao \& Lee, 2017). Twitter as a means of disseminating information has also proven to facilitate the coordination and integration of information between the central and local governments, such as the relationship between the ministry of health and local governments (figure 3).

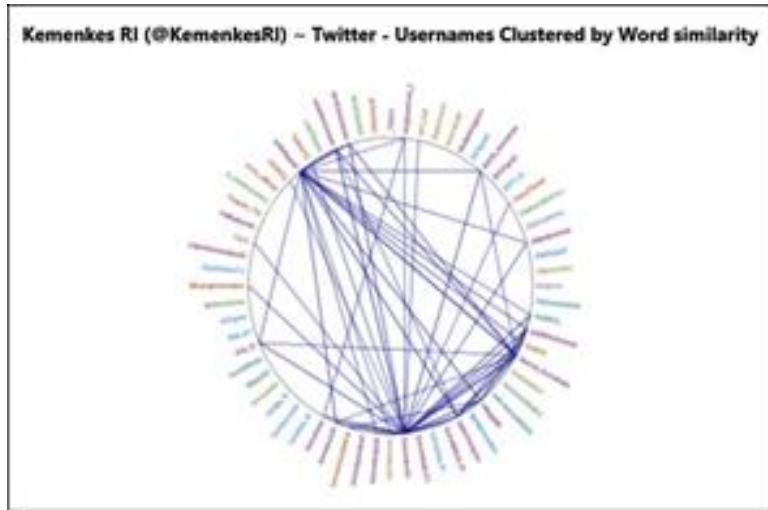

Figure 3 Communication Relationship Between

Central and Local Government, 2020.

Source : Processed by researchers using NVivo 12 Plus

Judging from the picture above, the central government through the @ KemenkesRI twitter account has been actively interacting through social media twitter with local government accounts, one of which is with the Dki Jakarta Regional Government, where DKI Jakarta is an area that has a high increase in Covid-19 cases. One of the information submitted through the Twitter account of the Ministry of Health of the Republic of Indonesia is related to Covid-19 information both from case reports, covid-19 prevention information and some policies carried out by the central government itself. It is evident that communication interactions conducted by @ KemenkesRI are clearly carried out with several local government accounts through @DKIJakarta accounts as well as other local government accounts such as to provide information disclosure related to covid-19 cases. In addition, there is also visible communication with government agencies that also participate in handling the prevention of covid-19 in the community such as with the cabinet secretariat through the Twitter account @ setkabgoid. Not only with the cabinet secretariat as a high stakeholder, but also actively communicating with WHO INDONESIA where this institution is actively involved in preventing and handling covid-19, it is seen that the central government's communication with the accounts of @DKIJakarta, @Bandung_Dinkes, @HumasBdg, @ Kabarsleman, @humasjateng,@JatimPemprov and @BNPB_Indonesia. So it can be concluded that the communication of the central government with local government, especially DKI Jakarta is quite actively discussing with Covid-19 both case information and prevention and handling measures of covid-19. By providing such information is also able to create interactive communication with the twitter user community this is seen a fairly relative reply from netizens. Because during this pandemic, the government has an important role to provide information related to covid19 clearly to the public. and social media is able to support the rapid dissemination of government information to help overcome this pandemic (Zeitzoff, 2017).

After the announcement of the first case of Covid-19, regional heads in Indonesia began to intensively conduct socialization related to Covid-19 mitigation. One of the earliest to give public information related to Covid-19 is the governor of DKI Jakarta, Anies Baswedan, then followed by several other regional heads. The role of local governments during the pandemic is very important, they are required to socialize local policies as well as transparency of covid-19 data through existing social media both personal accounts of regional heads and 
collective accounts owned by local governments, considering the use of social media has proven to increase community responsiveness (Eom, Hwang, \& Kim, 2018) and also proved to play a role in increasing government accountability by a significant number (Porumbescu, 2016; Song \& Lee, 2016).

According to (Yunus \& Rezki, 2020) stated that Indonesia has experienced a condition where people's concern for covid19 is quite large, so it is necessary for the government policy to conduct Lockdown, as an effort to break the link of the spread of the Covid-19 coronavirus. While according (Sahya Anggara, Slamatul Afiyah, Ai Siti Farida, 2020). The current policy is still normal, which from the beginning of handling and also its impact on the concept of new concepts of public policy innovation, which is expected to provide more concrete results and increase more sustainable community participation. Innovation in public policy must be applied in the early stages of formulation, implementation. Similar to the opinion (Engkus, Suparman, Sakti, \& Anwar, 2019), said that the Policy does not put seriousness on the focus of the problem and is immeasurable in the context of handling the covid 19 outbreak. In addition, the absence of national command from the central government is known to be slow in preventing the transmission of Covid-19 which has become a global disaster (Zahrotunnimah, 2020) . Its role in using a comprehensive communication strategy for all local governments. Drawing conclusions from some government researchers should be wiser in decision making in tackling Covid-19.

\section{CONCLUSION}

Corona virus that emerged from 2019 became a worldwide pandemic due to the rapid and easy nature of transmission of this virus that attacks humans who make physical contact. Due to the rapid nature of transmission, there needs to be serious treatment from the government. The most effective way that can be done by the government is by doing social distancing or social restrictions, self quarantine, and regional quarantine. The policy is a recommendation from the central government that is communicated to the local government. Jakarta is the first area to confirm a positive case of COVID-19 in Indonesia. Thus, the Jakarta regional government needs to respond quickly in mitigating the handling of COVID- 19 . Although the policy needs approval from the center, the local government can give policy decisions to its own regions. This is a characteristic of a region that has implemented the principle of decentralization. The role of local governments during the pandemic is very important, they are required to socialize local policies as well as transparency of covid-19 data through existing social media both personal accounts of regional heads and collective accounts owned by local governments, considering the use of social media has proven to improve community responsiveness. Various policies have been implemented by local governments such as by implementing regional quarantine, social restrictions, self-quarantine for people returning from traveling. Thus, it can be said that the role of local governments in handling COVID-19 has been able to respond quickly to increase the rate of COVID-19 transmission with the presence of several policies both from the center itself and from the region itself. Thus, the communication relationship between the central government and the government in providing policies related to handling Covid19 is able to be well integrated through communication conducted through social media.

\section{REFERENCES}

Abidin, Y. Z. (2016). Komunikasi Pemerintahan Filosofi, Konsep dan Aplikasi. Bandung: CV Pustaka Setia. 
Alfiani, F., Kurniawati, T., \& Siwi, M. K. (2018). Pengembangan Webtoon Untuk Pembelajaran Ips (Ekonomi) Di Smp. Jurnal Ecogen, 1(2), 439. https://doi.org/10.24036/jmpe.v1i2.47 66

Anggreani, M. D., Purnomo, E. P., \& Kasiwi, A. N. (2020). Ruang Publik Virtual Sebagai Pintu Komunikasi Government To Citizen (Studi Perbandingan Media Sosial Pemerintah Kota Yogyakarta dan Surabaya). Jurnal MODERAT, 6(1), 203-220. Retrieved from https://jurnal.unigal.ac.id/index.php/m oderat/article/view/3165/2919

Ansori, Y. Z. (2020). Penguatan Karakter Religius Siswa Melalui Pembelajaran Sains Bernuansa Pendidikan Nilai. BIO EDUCATIO : (The Journal of Science and Biology Education), 5(1), 57-64. https://doi.org/10.31949/be.v5i1.2123

Bachri, B. (2010). Meyakinkan Validitas Data Melalui Triangulasi. 2014-2017.

Bayu, D. J. (2020). Jumlah Kasus Positif Corona di Indonesia Tembus 1.000 Orang. Katadata.Co.Id.

Belkahla Driss, O., Mellouli, S., \& Trabelsi, Z. (2019). From citizens to government policy-makers: Social media data analysis. Government Information Quarterly, 36(3), 560-570. https://doi.org/10.1016/j.giq.2019.05.0 02

Chen, H., Guo, J., Wang, C., Luo, F., Yu, X., Zhang, W., ... Zhang, Y. (2020). Clinical characteristics and intrauterine vertical transmission potential of COVID-19 infection in nine pregnant women: a retrospective review of medical records. The Lancet, 395(10226), 809-815. https://doi.org/10.1016/S01406736(20)30360-3

Chinazzi, M., Davis, J. T., Ajelli, M., Gioannini, C., Litvinova, M., Merler, S., ... Vespignani, A. (2020). The effect of travel restrictions on the spread of the 2019 novel coronavirus (COVID19) outbreak. Science (New York, N.Y.), 9757(March), 1-12. https://doi.org/10.1126/science.aba975 7

Engkus, Suparman, N., Sakti, F. T., \& Anwar, H. S. (2019). Covid-19: Kebijakan Mitigasi Penyebaran Dan Dampak Sosial Ekonomi Di Indonesia. Journal of Chemical Information and Modeling, 53(9), 1689-1699. https://doi.org/10.1017/CBO97811074 15324.004

Eom, S. J., Hwang, H., \& Kim, J. H. (2018). Can social media increase government responsiveness? A case study of Seoul, Korea. Government Information Quarterly, 35(1), 109-122. https://doi.org/10.1016/j.giq.2017.10.0 02

Ferguson, N. M., Laydon, D., NedjatiGilani, G., Imai, N., Ainslie, K., Baguelin, M., ... Ghani, A. C. (2020). Impact of non-pharmaceutical interventions (NPIs) to reduce COVID19 mortality and healthcare demand. (March), 20. https://doi.org/10.25561/77482

Gregory, A. (2006). A development framework for government communicators. Journal of Communication Management, 10(2), 197-210.

https://doi.org/10.1108/136325406106 64742

Gupta Thuy Nguyen Felipe Lozano Rojas Shyam Raman Byungkyu Lee Ana Bento Kosali I Simon Coady Wing, S. D., Hollingsworth, A., Freedman, S., Sacks, D., Samyn, J., Sumedha Gupta, by, ... Gupta, S. (2020). Tracking Public and Private Responses to the COVID-19 Epidemic: Evidence from State and Local Government Actions. National Bureau of Economic Research. https://doi.org/10.3386/w27027 
Hopman, J., Allegranzi, B., \& Mehtar, S. (2020). Responding to Covid-19 - A Once-in-a-Century Pandemic? Jama. https://doi.org/10.1056/NEJMp200376 2

Kosasih, I. (2016). PERAN MEDIA SOSIAL FACEBOOK DAN TWITTER DALAM MEMBANGUN KOMUNIKASI (Persepsi dan Motifasi Masyarakat jejaring Sosial Dalam Pergaulan). Journal of Chemical Information and Modeling, 53(9), 1689-1699.

https://doi.org/10.1017/CBO97811074 15324.004

Nicomedes, C. J. C., \& Avila, R. M. A. (2020). An analysis on the panic during COVID-19 pandemic through an online form. In Journal of Affective Disorders (Vol. 276). https://doi.org/10.1016/j.jad.2020.06.0 46

Porumbescu, G. A. (2016). Comparing the Effects of E-Government and Social Media Use on Trust in Government: Evidence from Seoul, South Korea. Public Management Review, 18(9), 1308-1334.

https://doi.org/10.1080/14719037.2015 .1100751

Riyanto, A. D. (2014). PEMANFAATAN GOOGLE TRENDS DALAM PENENTUAN. 2014(semnasIF), 52 59.

Sahya Anggara, Slamatul Afiyah, Ai Siti Farida, J. M. (2020). Kata Kunci : Inovasi Kebijakan Publik, Penanggulangan Corona Virus Disease 19 (Covid-19) Jawa Barat 1. Kunci, Kata Publik, Inovasi Kebijakan Corona, Penanggulangan Disease, Virus Barat, Jawa, 19.

Silalahi, U. (2004). Komunikasi pemerintahan: mengirim dan menerima informasi tugas dan informasi publik. 3(1), 36-54.

Solahudin, D., Eif, D., Amin, S., Sumpena, D., \& Hilman, F. A. (2020). Analisis kepemimpinan di Indonesia dalam kerangka tanggap-darurat Covid-19 Digital Library UIN Sunan Gunung Djati Bandung. Digital Library UIN Sunan Gunung Djati Bandung. Retrieved from http://digilib.uinsgd.ac.id/30637/

Song, C., \& Lee, J. (2016). Citizens Use of Social Media in Government, Perceived Transparency, and Trust in Government. Public Performance and Management Review, 39(2), 430-453. https://doi.org/10.1080/15309576.2015 .1108798

Spectatorindex. (n.d.). No Title.

Sugiyono. (2018). Metode Penelitian Kualitatif: Untuk penelitian yang bersifat eksploratif, enterpretif, interaktif dan konstruktif (Edisi ke-3; S. Y. Suryandari, Ed.). Bandung: ALFABETA.

Thorik, S. H. (2020). Efektivitas Pembatasan Sosial Berskala Besar Di Indonesia Dalam Penanggulangan Pandemi Covid-19. Jurnal Adalah: Buletin Hukum Dan Keadilan, 4 No. 1, 115120.

Wilder-Smith, A., \& Freedman, D. O. (2020). Isolation, quarantine, social distancing and community containment: Pivotal role for old-style public health measures in the novel coronavirus (2019-nCoV) outbreak. Journal of Travel Medicine, 27(2), 1-4. https://doi.org/10.1093/jtm/taaa020

Yunus, N. R., \& Rezki, A. (2020). Kebijakan Pemberlakuan Lock Down Sebagai Antisipasi Penyebaran Corona Virus Covid-19. SALAM: Jurnal Sosial Dan Budaya Syar-I, 7(3). https://doi.org/10.15408/sjsbs.v7i3.150 83

Zahrotunnimah, Z. (2020). Langkah Taktis Pemerintah Daerah Dalam Pencegahan Penyebaran Virus Corona Covid-19 di Indonesia. SALAM: Jurnal Sosial Dan Budaya Syar-I, 7(3). https://doi.org/10.15408/sjsbs.v7i3.151 
03

Zed, M. (2014). Metode Penelitian Kepustakaan. Jakarta: Yayasan Obor Indonesia.

Zeitzoff, T. (2017). How Social Media Is
Changing Conflict. Journal of Conflict Resolution, 61(9), 1970-1991. https://doi.org/10.1177/002200271772 1392 